\title{
A Review of the Environmental Authorization Followed During the Construction of Eskom's Kusile and Medupi Power Stations, South Africa
}

\author{
Shadung John Moja²,3, Mamonene Emmy Molepo ${ }^{1,2 *}$, and Gladness Madibakisha Chadi \\ ${ }^{1}$ Eskom Holdings SOC, Megawatt Park, 1 Maxwell Drive, Johannesburg, South Africa \\ ${ }^{2}$ Department of Environmental Sciences, University of South Africa, Florida Science Campus, Roodepoort, South Africa \\ ${ }^{3}$ Sustainable Resources and Environment Competency, Council of Geoscience, 280 Pretoria Street, Silverton, Pretoria, South Africa
}

\begin{abstract}
Environmental impact assessment follow-up has been widely addressed by various researchers. However, there is still a gap in the actual implementation of this process. This study was aimed at addressing this gap by evaluating the effectiveness of implementing the environmental authorizations of South African Eskom's Kusile and Medupi Power Stations during the construction phase. The main focus was to determine whether the environmental authorization conditions are effectively implemented by project developers and whether full compliance which could lead towards sustainable developments is at the forefront of Kusile and Medupi Power Stations construction developments. The survey data collection method was used whereby questionnaires were formulated and completed by 50 participants involved in the implementation of both power stations' environmental authorizations. The results of the study showed that the power stations understand the importance of protecting the environment and complied with the overall projects' environmental authorization conditions. The external audit results stretching for six years have shown over $90 \%$ compliance with the environmental authorization at both power stations. These results confirm that the environmental management through compliance with the environmental authorization is at the forefront of the Eskom's developments and thus promotes sustainable development. The outcome of this study has a wide application that includes being applied to any new project that involves building infrastructure.
\end{abstract}

Keywords: Environmental authorization; Environmental impact assessment; Power station; Environmental impact assessment followup; Compliance

\section{Introduction}

The construction of new power stations generally triggers different environmental licenses such as water use license (WUL) and atmospheric emission license (AEL) to be acquired prior to the commencement of such projects. In South Africa, one of the these licenses' condition is the environmental authorization (EA) which is required in terms of Section 24 of National Environmental Management Act, Act No 107 [1]. The $\mathrm{EA}$ is one of the permits or license issued following the process of the environmental impact assessment (EIA) or basic assessment (BA) on a project.

Wood [2] explains the EIA as an anticipatory, participatory, integrative environmental management tool that has the objective of providing authorities with an indication of the likely consequences of their decisions relating to new developments. Wood [2] further explains EIA as the tool to evaluate the possible effects likely to arise from a development which will significantly affect the natural and manmade environment, The EIA process in South Africa (SA) is regulated by the National Environmental Management Act 107 [1] and the custodian of the act is the Department of Environmental Affairs (DEA). NEMA has set out the EIA regulations, 2014 as amended, which has three listing notices that list the activities that require basic assessment or scoping and EIA process to be undertaken and the license which is the environmental authorization (EA) is issued by DEA prior commencement of such activities.

A project may only commence once the EIA process has been undertaken, completed and the EA has been issued. However, like any other license, the EA comes with conditions that the project has to comply with. Therefore, this research focuses on how effective are the EA conditions implemented and complied with during the construction phases of both Eskom' Kusile and Medupi Power Stations. Eskom Holdings Limited [3] is a state owned company that is mandated to generate, transmit and distribute electricity throughout South Africa (the country) and to neighboring countries [4].

\section{Kusile power station case study}

Kusile Power Station (Kusile) is located in Delmas Local Municipality within Nkangala District Municipality of Mpumalanga Province in South Africa outside Emalahleni town commonly known as Witbank, as indicated in Figure 1. According to Eskom [4], Kusile is a coal-fired power station with a site of about 1355 hectares (ha) in size, and is located on the farm Hartbeesfontein 537 JR and farm Klipfontein 566 JR. Kusile is the most advanced coal-fired power plant project in Eskom after Medupi Power Station in Lephalale where construction activities are currently underway and began in 2008 .

The EIA for Kusile was conducted between 2005 and 2007 [5]. Its EIA followed just after the Medupi Power Station EIA [6]. The EA was first issued on 05 June 2007 and amended EA was issued after the review of two appeals on 17 March 2008 by DEA.

Kusile EA was issued in terms Section 21 and 22 of the Environment Conservation Act (ECA), Act No 73 [7] and regulation of Government Notice R 1182 of 1997. The authorised activities are shown in Table 1.

*Corresponding author: Mamonene Emmy Molepo, Department of Environmental Sciences, University of South Africa, Florida Science Campus, Roodepoort, South Africa, Tel: +27828600919; E-mail: molepome@eskom.co.za

Received November 01, 2016; Accepted November 10, 2016; Published November 14, 2016

Citation: Moja SJ, Molepo ME, Chadi GM (2016) A Review of the Environmenta Authorization Followed During the Construction of Eskom's Kusile and Medup Power Stations, South Africa. J Remote Sensing \& GIS 5: 176. doi: 10.4175/2469 4134.1000176

Copyright: ( 2016 Moja SJ, et al. This is an open-access article distributed under the terms of the Creative Commons Attribution License, which permits unrestricted use distribution, and reproduction in any medium, provided the original author and source are credited. 
Citation: Moja SJ, Molepo ME, Chadi GM (2016) A Review of the Environmental Authorization Followed During the Construction of Eskom's Kusile and Medupi Power Stations, South Africa. J Remote Sensing \& GIS 5: 176. doi: 10.4175/2469-4134.1000176

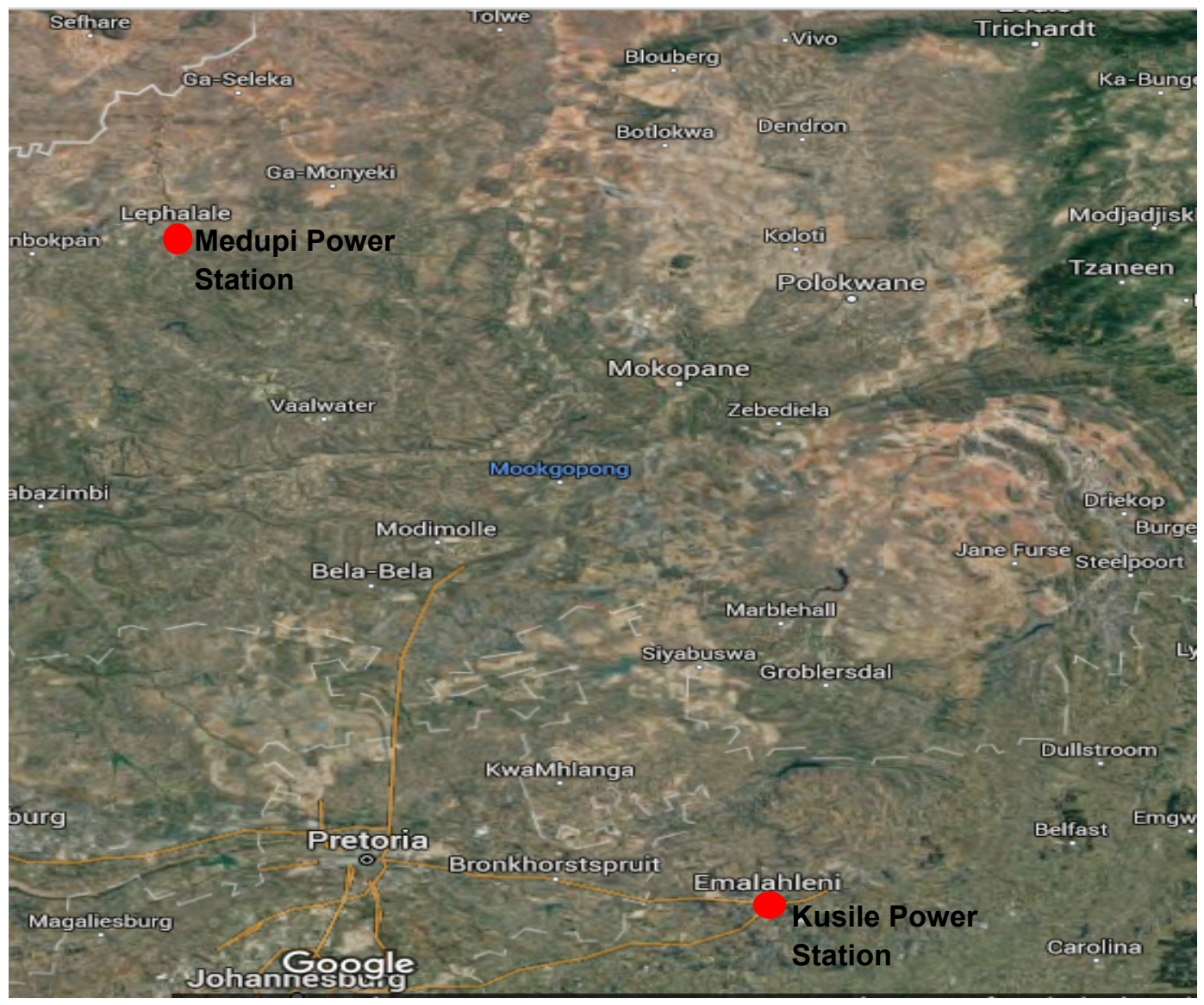

Figure 1: Kusile and Medupi Power Station location [26].

\begin{tabular}{|c|c|}
\hline Listed Activity & Authorised activities description in terms of EIA Regulation R 1182 of 1997 \\
\hline Item 1 & $\begin{array}{l}\text { The construction, erection or upgrading of: } \\
\text { Item 1(a). facilities for commercial electricity generation with an output of at least } 10 \text { megawatts and infrastructure for bulk supply; } \\
\text { Item 1(c). with regard to any substance which is dangerous or hazardous and is controlled by national legislation: } \\
\text { infrastructure, excluding road and rails, for the transportation of any substances; and } \\
\text { - manufacturing, storage, handling, treatment or processing facilities for any such substance; } \\
\text { Item 1(d). roads, railways, airfield and associated structures; } \\
\text { Item 1(g).structures associated with communication networks, including masts, towers and reflector dishes } \\
\text { Item 1(i).schemes for the abstraction or utilisation of ground or surface water for bulk supply purpose; } \\
\text { Item 1(n).sewage treatment plants and associated infrastructure }\end{array}$ \\
\hline Item 2 & $\begin{array}{l}\text { The change of land use from } \\
\text { Item } 2 \text { (c). agriculture or zoned undetermined use or equivalent zoning to any other land use }\end{array}$ \\
\hline Item 8 & $\begin{array}{l}\text { The disposal of waste as defined in Section } 20 \text { of the Act (ECA), excluding domestic waste, but including the establishment, expansion, upgrading } \\
\text { or closure of facilities for all waste, ashes and building rubble. }\end{array}$ \\
\hline
\end{tabular}

Table 1: Kusile authorised listed activities in terms of EIA Regulation R1182 of 1997 [16]

\section{Medupi power station case study}

Medupi Power Station (Medupi) is located in Waterberg District Municipality of Limpopo Province in South Africa outside Lephalale town near Maropong community, as indicated in Figure 1. According to Eskom [3] as a result of the increasing demand for electricity in South Africa, Eskom decided to increase its electricity generating capacity. Eskom decided to build a new coal-fired power station, named Medupi near Lephalale, consisting of six super critical boilers and 6 turbine generator units with air-cooled condensers. Medupi have a nominal generating capacity of $4800 \mathrm{MW}$. On completion Medupi Power Station will be the largest dry cooled power station in the world [4].

Medupi is the first Eskom coal-fired power station in South Arica whereby an EIA was conducted since the EIA regulations was first promulgated in South Africa in 1997 in terms of the EIA Regulations 1182 as set under Environment Conservation Act, Act No. 73 [7]. All the Eskom previous or old power stations were constructed before then hence the EIA was not conducted. From Medupi followed the Kusile and Ingula Power Stations where the EIA was also conducted [6].

The Medupi EIA was conducted between 2003 and 2006 [8]. The EA was issued by DEA on 21 September 2006 in terms Section 21 and 22 of the Environment Conservation Act (ECA), Act No 73 [7]. The project construction commenced in early 2007 and is currently underway with the first unit been operational since March 2015 [9]. The research focuses on the Medupi EA compliance of the past eight years till end April 2015. The authorised activities are indicated in Table 2 below. 


\begin{tabular}{|c|c|}
\hline Listed Activity & Authorised activities description in terms of EIA Regulation R1182 and R 1183 of 1997 \\
\hline Item 1 & $\begin{array}{l}\text { The construction, erection or upgrading of: } \\
\text { Item 1(a). facilities for commercial electricity generation with an output of at least } 10 \text { megawatts and infrastructure for bulk supply; } \\
\text { Item 1(c). with regard to any substance which is dangerous or hazardous and is controlled by national legislation: } \\
\text { infrastructure, excluding road and rails, for the transportation of any substances; and } \\
\text { - manufacturing, storage, handling, treatment or processing facilities for any such substance; } \\
\text { Item 1(d). roads, railways, airfield and associated structures; and } \\
\text { Item 1(n). sewage treatment plants and associated infrastructure. }\end{array}$ \\
\hline Item 2 & $\begin{array}{l}\text { The change of land use from } \\
\text { Item 2(c). agriculture or zoned undetermined use or equivalent zoning to any other land use }\end{array}$ \\
\hline Item 9 & $\begin{array}{l}\text { Scheduled processes listed in the Second Schedule to the Atmospheric Pollution Prevention Act (APPA), Act No } 45 \text { of } 1965 . \\
\text { Process } 29(a) \text { - Power generation processes in which fuel is burned for the generation of electricity for distribution to the public or for purposes } \\
\text { of public transport. }\end{array}$ \\
\hline
\end{tabular}

Table 2: Medupi authorised listed activities in terms of EIA Regulation R1182 and R1183 of 1997 [3].

This research study investigated how the EA conditions are being complied and implemented by the development using the two identified case studies, Kusile and Medupi Power Stations. This was done by determining the effectiveness of complying with the EA conditions during construction phases, and identifying challenges encountered during the EA implementation related to environmental management.

This research study is slightly similar to EIA follow-up. The study looks at the consequences of the EA conditions implementation on the environment (i.e., the practical effects that are relevant to the environment) and how well monitoring is conducted as there are structured monitoring and audits at these two power stations.

It further aimed at determining the effectiveness of implementing and complying with the EA conditions during construction phase. Whereas EIA follow-up monitors and evaluates the impacts of a project that was subjected to EIA for the purpose of managing and communicating the environmental performance of such a project [10].

\section{Materials and Methods}

The research methodology used in this research study is the mixed method as it combined both the elements of qualitative and quantitative methods. Qualitative data was collected from the power stations and analysed, while the quantitative data involved a questionnaire method. The research strategies or approaches used in this study are case studies and non-experimental design such as a survey in a form of structured interviews and questionnaires. The methodology was used according to Creswell [11] theory. The case study design approach and survey method were appropriate for this research study as it assisted in looking into specific project activities in order to determine the effectiveness of implementing EA conditions to such projects activities.

The case studies used for this research study are Eskom' Kusile and Medupi Power Stations. These two developments are the mega projects in South Africa for the generation of electricity. The developments have both acquired environmental authorizations with which they should comply with. This study was therefore assessing the effectiveness of such compliance with the acquired EAs.

The survey research method in a form of questionnaires was also appropriate in this study as it assisted in determining the understanding of the project implementers to EA compliance.

Three site visits were conducted per power station between February and October 2015. This was for making observations related to the practical way of doing things particularly compliance with the projects EA conditions. Field notes and photographs were taken on site and findings captured.

Photographs provide the state of the environment at a specific time and serve as proof of observations made during site visits. Most authors such as Youthed, Jordaan and Eskom [12-14] made use of photographs to elaborate their statements.

All site visits were arranged through a telephone and formal outlook appointment created and sent to each power station environmental manager and their team. The environmental officials were responsible for taking the researcher through the site visits. The first site visit was for familiarization with the projects sites and location, meeting the project implementers, observation of how the EA is implemented, taking photo graphs, obtaining data such as copies of EAs, environmental audits reports, incidents reports etc.

Obtaining copies of the EAs for both the power stations, made it easier to be aware of the conditions the projects are expected to comply with. The audit reports assisted in understanding the projects compliance over the years since construction commenced in 2007 for Medupi and 2008 for Kusile. Photographs assisted in elaborating the observations made during the site visits and putting the content in a picture for better understanding of the report reader.

The second visit was conducted mainly to meet participants for the completion of the questionnaires. Questionnaires were initially sent through to participants via emails. The power stations environmental managers assisted with distribution to the target group but very few responses were received. The target group was determined by identifying key participants who are involved in the EA implementation. These were mainly the environmental practitioners, project coordinators or managers, engineers and ground workers.

The third site visit was initiated to finalize the completion of questionnaires by participants for Medupi as well as collecting outstanding data such as the environmental management committee terms of reference for Kusile.

\section{Data analysis and interpretation}

Data analysis used for this research study was data coding and content analysis. Whereby text data from documents such as EA, environmental audit reports, environmental monitoring committee reports and incident reports; site observations and site photographs (both gathered during data collection and captured during the site visits) were segmented into categories given a single term and information analyzed.

The results were analysed and interpreted in terms of the research problem. This analysis tries to explain the results meaning and implication in the light of the purpose of the research study, as adopted per Welman and Kruger [15] theory. This theory involves indicating the meaning and implication of the finding in light with the research purpose. EA conditions were assessed individually and proof of compliance requested. The use of graphs, diagrams and charts were also used to assist in elaborating the results. 


\section{Results and Discussion}

\section{Kusile power station}

Lodged environmental authorization appeals: The first EA issued for Kusile on 05 June 2007 by DEA was appealed by at least two members of the public, a landowner who is a local farmer in the area and the poultry farm. The appeals were submitted to DEA shortly after the decision (EA) was issued to Kusile [16].

The appeal was undertaken in terms of Section 35 (3) of the Environment Conservation Act, Act No. 73 [7] which states that "... any person who feels aggrieved at a decision of an officer or employee exercising any power delegated to him in terms of this Act or conferred upon him by regulation, may appeal against such decision to the Minister or the competent authority concerned...”. The grounds of appeals are:

- According to the landowner and a farmer, there was no consultation on the project

- The ash dump will be detrimental to the health of the farmer' family and animals

- A normal way of life and living for the farmer and his family will be impacted upon

- No assessment was done with regard to the cumulative impacts of the proposed power station and the other mine in the same area, etc.

On receiving these appeals, DEA investigated and dismissed the appeals lodged against the decision of Kusile EA issued on 05 June 2015, and to grant the EA for the construction of the proposed Kusile Power Station and its associated infrastructure [16]. DEA also revised the issued EA with the new EA issued on 17 March 2008 in order to address the received appeals concerns. And the added conditions were as follows [16]:

- The applicant, in consultation with the relevant appellant (poultry farm) should, on a quarterly basis, monitor the reproductive health of the poultry on the appellant' farm and if it is conclusively established that there is a causal connection between the emissions from the power station and any deterioration in the health of the chickens, corrective measures should be implemented by the applicant (Kusile); and

- The applicant should establish an ambient air quality monitoring station to monitor the ambient air impact of the power station

Unauthorized stream diversion: The Kusile EA was issued in terms of the ECA, schedule 1 regulation $\mathrm{R} 1182$ and most of the activities were not covered by ECA list of activities requiring the EIA to be undertaken. However, Kusile only commenced with construction in 2008 and by then the EIA list of activities had been revised and repealed by the 2006 EIA Regulations, GN R385 [17].

Kusile EA authorised the development among others the power station; coal stock yard; coal and ash conveyors; ash disposal facility/ dump; water and wastewater treatment facilities; access roads; a dam and railway line. However, it did not authorise the activity within a watercourse for diverting the stream. This activity was neither accessed during the EIA process nor applied for [18]. It has to be noted that even though the EA did not mention and authorise this activity, a water use license (WUL) for diverting the stream was acquired and approved by the Department of Water and Sanitation (DWS) in April 2011.
The power station diverted a natural stream running south of the power station plant to cater for the required construction of the coal stock yard and its conveyor belts. As a result this activity contravened Section 24F of NEMA which states that "notwithstanding any other act, no person may commence an activity listed or specified in terms of Section 24 (2) (a) or (b) unless the competent authority has granted an environmental authorization for the activity" and required that Section $24 \mathrm{G}$ of NEMA for the rectification application for commencing with a listed activity without authorization be applied for. This EIA rectification application was then undertaken between 2010 and 2012. The rectification EA was issued on 26 July 2012 by DEA.

Due to the nature of the power station' construction, most activities unfolds as the construction progresses [19]. This becomes a challenge to ensure compliance with all current related legislations as most of the activities now requires EIA to be undertaken prior commencement of such activities. As a result the power station has other EIAs currently underway for such activities. This is to ensure Kusile' compliance with current and related legislations as well as avoiding any legal contravention as had occurred with the stream diversion.

The Kusile lessons learnt on the legal contravention of the stream diversion was shared with all the Eskom Environmental Practitioners at an annual environmental conference held in Johannesburg in 2012. Among the other lesson learnt it was that the EIA Project Manager should ensure that all the activities of a proposed development are assessed and applied for and avoid much reliance on the EAP running the EIA (Eskom).

Potential wetland destruction: The original design of the 10 year ash disposal facility authorised together with the main power station EA, was covering the wetland area. However, the acquired WUL from DWS only authorised Section $21(\mathrm{~g})$ of the National Water Act, Act No. 36 of 1998 which state that "disposing of waste in a manner which may detrimentally impact on a water resource" and did not authorised Section 21 ( $c$ and i) of the same Act which state that "impending or diverting the flow of water in a watercourse and altering the bed, banks, course or characteristics of a watercourse".

The project team at Kusile was able to pick this unauthorized activity prior to construction and has stopped the construction of the ash disposal facility near to the wetland area, while the WUL was applied for. The WUL was eventually issued by DWS in 2009.

Excessive vegetation clearance: During the site visit conducted on the 01 April 2015 it was observed that the vegetation clearance unlike at Medupi which has more indigenous vegetation cover within and around the development area, Kusile's vegetation has been excessively removed within the development area. It however has to be noted that the vegetation around and within Kusile' surroundings are minimal and mostly grasses and shrubs. This was also mentioned and a concern to Eskom [20].

Rehabilitation and other required permits: EA condition 3.16.1 requires that no exotic plant species may be used for rehabilitation purposes and only indigenous plants may be used. Furthermore EA condition 3.17 requires that other legislations such as the National Heritage Resource Act, Act No. 25 [21]; Occupational Health and Safety Act, Act No. 85 of 1993; National Water Act, Act No. 36 of 1998; and others should also be complied with.

Kusile developed a plant nursery at the power station area where the indigenous plants from the search and rescue exercise are kept. Their plan is to return the plants back after construction as part of 
Citation: Moja SJ, Molepo ME, Chadi GM (2016) A Review of the Environmental Authorization Followed During the Construction of Eskom's Kusile and Medupi Power Stations, South Africa. J Remote Sensing \& GIS 5: 176. doi: 10.4175/2469-4134.1000176

Page 5 of 9

rehabilitation purpose and also complying with EA condition 3.16.1. Kusile further acquired a permit for removal of indigenous protected plants from the Mpumalanga Tourism and Park Agency.

Water quality management: The public complains that were received by Kusile were of more sediments downstream of the power station and the poor water quality [20].

Access road: The access road to the power station is crossing a number of streams and wetlands. By the time Kusile needed to commence with its construction, the WUL was not yet approved by DWS. The project team in agreement with DWS decided to commence with road portions that did not affect streams and wetlands so as to not delay the development process. The portions affecting streams and wetlands were constructed later when the WUL was issued in October 2009.

Graves relocation: Kusile had graves that were relocated, most of the graves and old houses where identified during the EIA phase. Another heritage assessment study phase 2 was conducted in order to relocate the graves; about two hundred (200) graves were relocated to a cemetery in Phola human settlement near Kusile (Kusile Environmental Manager, 2015). The old houses were also demolished to allow for the power station construction. The process occurred between 2008 and 2010; the heritage permit was acquired in 2010 issued by the South African Heritage Resources Agency (SAHRA).

Air quality management: Requirements of the air quality management are required in EA condition 3.7. Among others Kusile is required to initiate program of support for initiatives aimed at improving quality in the Witbank residential area, and that the program should be included in the operational EMP.

External audits: The external audits are conducted biannually by an external environmental consultant at Kusile. However, this is not a specific requirement of the EA condition. The EA only requires the records of monitoring and audits to be kept and submitted to DEA. This means no limitations to who can conduct audits; it may be internal or external personnel. It is of best practice for Kusile to contract with an external auditor to ensure unbiased process.

These external audits commenced in 2009 and have been carried out till to date. The results of all the nine audits reports conducted since 2009 to 2013 indicate compliance to both the EA conditions and the
EMP of over 90\%, as indicated on the graph in Figure 2. Most of the few identified non-compliances at the times of audits were addressed.

The compliance started at high rate of $91 \%$ in June 2009 and even higher in February 2010 at $98.26 \%$ but went slightly down in July 2010 at $96.8 \%$. Compliance went further down in February 2012 at $95.8 \%$ however picked up on August 2012 to nearly $100 \%$ at $99.5 \%$. The graph shows compliance results of over $90 \%$ for all audits conducted.

\section{Medupi power station}

Air quality management: EA condition addresses the requirements for the air quality management at the power station and its surroundings. It indicates that Medupi should initiate a program for the continuous monitoring of ambient concentrations of pollutants in the Marapong human settlement and surrounding areas.

Furthermore, unlike Kusile the EA specifically indicates that Medupi should install commission and operate any required Sulphur dioxide abatement measures that may be necessary to ensure compliance with any applicable emission or ambient air quality standards published in terms of the National Environmental Management: Air Quality Act, (Act No.39 of 2004). Medupi has two ambient air quality monitoring stations installed at the Marapong human settlement and Kroomdraai farm, as Marapong and Medupi air quality monitoring (AQM). The monitoring stations also monitor impact from the nearby Eskom Matimba Power Station (Matimba) which is also near Lephalale town.

The Kroomdraai monitoring station was installed in October 2014 and is about $5 \mathrm{~km}$ from Medupi. The Marapong monitoring station was installed as part of the Matimba project and is about $2.4 \mathrm{~km}$ from Matimba. As Medupi is still under construction, the stations currently monitor the baseline conditions prior to Medupi commissioning. However, it has to be noted that at the time of the site visit of 9 July 2015, Medupi' one unit out of six units was operational since March 2015 for testing phase [20]

Medupi also installed and uses the technology of a fabric air filter bags which assist in absorbing and/or reducing air emissions.

Monitoring and auditing: Medupi contracted an external independent environmental consultant to conduct bi-annual audits against compliance of all environmental permits and/or license at the power station. This is similar to Kusile however different consultants are been used for each power station. These external audits commenced in

\section{Kusile EA Compliance}

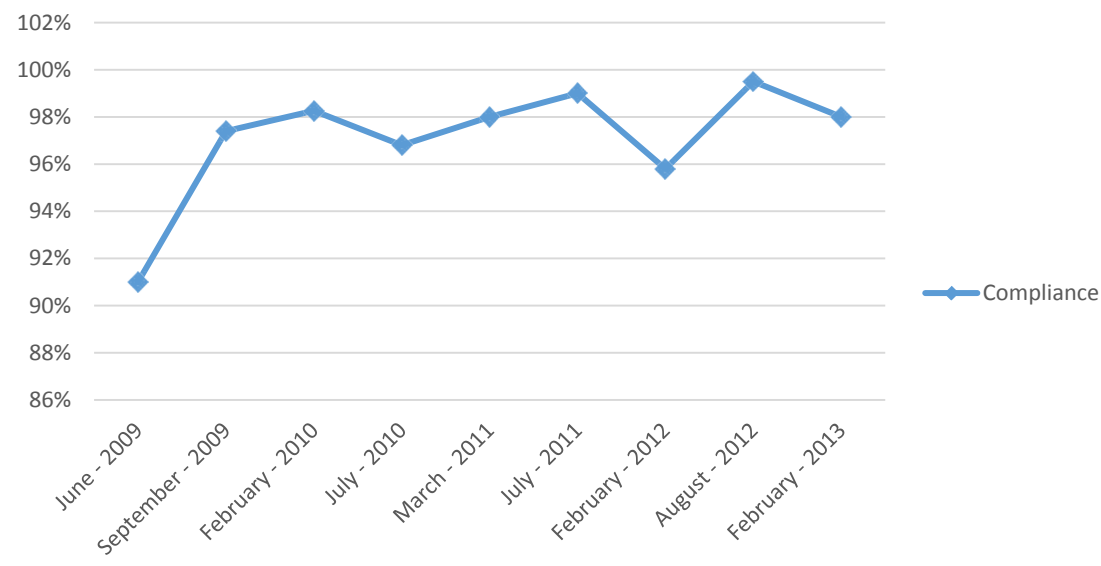

Figure 2: Kusile EA and EMP external compliance audits results. 
Citation: Moja SJ, Molepo ME, Chadi GM (2016) A Review of the Environmental Authorization Followed During the Construction of Eskom's Kusile and Medupi Power Stations, South Africa. J Remote Sensing \& GIS 5: 176. doi: 10.4175/2469-4134.1000176

Page 6 of 9

2008 and have been carried out till to date. The ten audits reports which are also submitted to DEA were reviewed from start of audits in 2008 to 2014; results are indicated on the graph in Figure 3.

This graph like Kusile indicates compliance results of over $90 \%$ throughout all audits conducted. However, Medupi' compliance is higher than the Kusile where compliance started at $92 \%$ in 2008 and went up reaching 100\% twice in November 2011 and May 2012. Compliance went slightly down in May 2013 and April 2014 but still above $98 \%$.

Heritage resources: EA condition 3.2.8 states that archaeological remains or resources if exposed during excavations for the purpose of laying foundations, construction should be stopped and an Archaeologist should be called to site for the inspection.

"On the $6^{\text {th }}$ June 2007, after the construction of Medupi has already commenced, an additional grave was located under a tree near the old school building" [22]. The process of locating the family was initiated and agreements reached to relocate the grave through a formal legal process of obtaining necessary permits. The investigation process enabled the establishment of identifying the deceased and the grave was relocated to the nearby Marapong human settlement cemetery [22].

Eskom [22] further mentioned that the discovery of this unmarked grave led to further heritage study or investigations by Eskom through the appointment of the Archaeologist. Subsequently, a number of graves claims by members of the human settlement were received and made in the same year.

According to Medupi Environmental Manager [23] the heritage study was to, firstly verifies whether the heritage assessment conducted during the EIA phase was correct and followed proper processes and legislation in terms of the National Heritage Resources Act, Act No. 25 [21].

Secondly, to validate claims of graves in the Medupi project area made by the community as there was no proof of affected graves in previous heritage assessment study conducted for the EIA [8]. However, further investigation of the site on which the power station is established did not reveal any further graves. Other few identified graves were not affected by the project area [22].
Water quality management: EA condition 3.2.9.1 requires Medupi to continuously monitor the ground water quality and implement measures to ensure that pollution of the water resources do not occur. Medupi established groundwater monitoring in 2007 and conducts quarterly monitoring.

Furthermore Medupi uses air cooled condenser (ACC) for its cooling purposes and not the method of normal wet or dry cooling towers that uses more water. The ACC further reduces visual impact and footprint space usage unlike the normal cooling towers.

Flora and fauna management: The site visit observation made showed more dense indigenous vegetation cover around the surrounding of the Medupi project area. Some vegetation cover has been left un-removed inside the power station and animals are able to roam around freely within the station. However, fewer incidents where animals were killed had occurred on site.

Gaps identified: During desktop review, site visits and interview conducted, it was noticed that the EAs did not cover other crucial aspects related to the Kusile and Medupi development as well as taking into account the development areas of Witbank and Lephalale. These missing crucial aspects within the EA are the identified gaps. Although most of these identified gaps were addressed in the projects' EMP, the extent importance of these aspects quantifies them to be included in the EA and not just the EMP only.

Storm water and soil erosion management: Kusile has a steep slope in some areas and the surroundings have less vegetation cover. This situation may be a potential trigger for soil erosion and run off water to drain quickly. The EA should have included conditions relating to management of storm water and soil erosion for the good of protecting the environment.

Dust suppression: Dust suppression was overlooked for both the power stations as no EA condition addressed it and the project of magnitude as Kusile and Medupi take very long over seven (7) years in construction phase. Even though selective vegetation clearance was undertaken; most clearance on active project areas is unavoidable. Therefore, dust suppression is necessary to reduce dust blow out.

\section{Medupi EA Compliance}

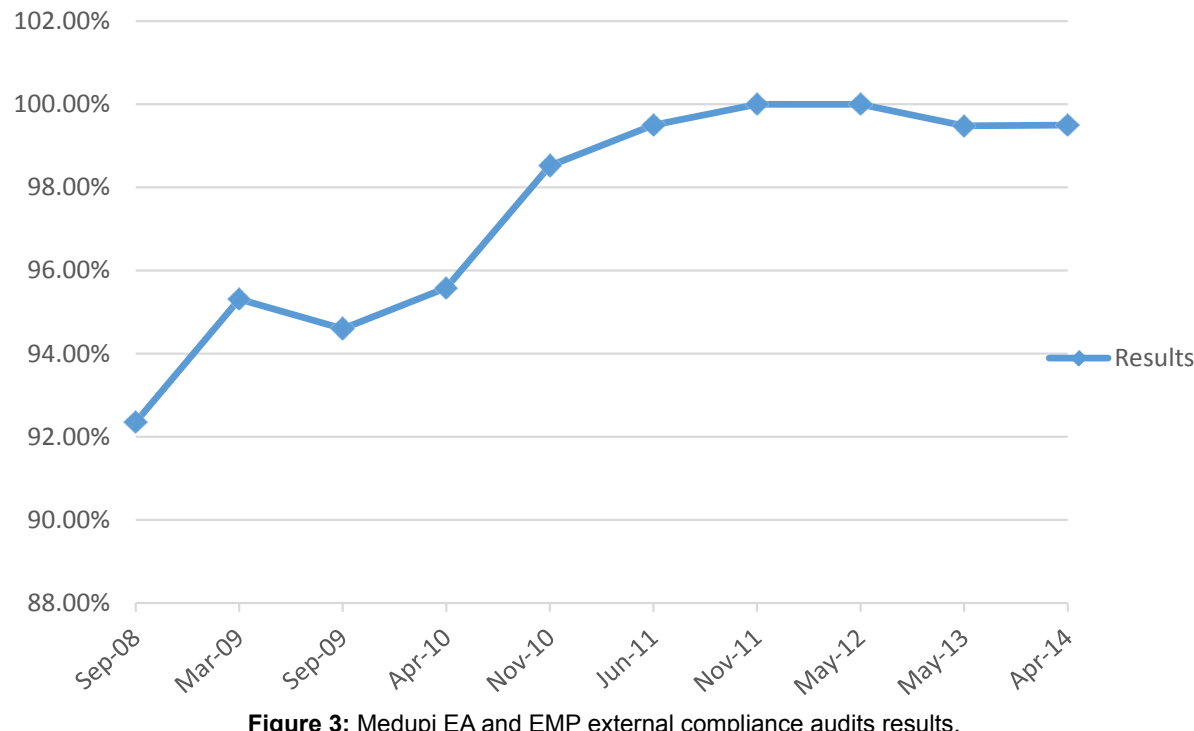


Water resource management: The development area of Kusile has more rivers and wetlands; hence more emphasis was on wetlands management on the EA was necessary. Furthermore, DEA' failure to require more clarity on how the wetland would be dealt with as the initial ash disposal facility design submitted with the FEIR covered the wetland area.

Air quality management: The EA condition addresses the requirements for the air quality management at Medupi and its surroundings. It indicates that Medupi should initiate a program for the continuous monitoring of ambient concentrations of pollutants in the Marapong human settlement and surroundings.

This condition requirement does not specify the period when to initiate the monitoring program. In comparison with the Kusile, monitoring station was installed in 2007 and construction commenced in 2008, whereas in Medupi the monitoring station was installed in 2014 and construction commenced in 2007. However, the Matimba Power Station (a power station near Medupi) monitoring station installed in Marapong human settlement was used by Medupi since 2007.

In the case of these related case studies, the power stations are not the only once in the vicinity of their location, as other existing similar power stations also owned by Eskom had already installed the required monitoring stations. This makes it easier for continual process of monitoring to cater for new power stations.

However, in a case where this condition may apply to a different project which does not have the existing monitoring stations in place, the condition may be missing enough clarity as developers can choose when to install the monitoring station. This can be once the project is operational aiming to monitor the operational impacts, and not necessarily when the project is under construction to monitor baseline conditions of an area. Therefore, the condition needs to specify the period or project phase when the monitoring station should be installed.

Noise: During Medupi site visit, the high volume of noise was experienced near and within the plant (electricity generating unit's buildings) construction area. The offices have ear piece plugs at each main door. The Senior Environmental Advisor (2015) explained a safety requirement of the power station to always wear ear plugs whenever one is going inside the plant. This is required as part of full personal protective clothing which includes among other things hard hats, reflector jacket, safety shoes, etc. This safety related requirement was also not addressed by the EA.

External auditing/monitoring: The EA did not specifically request the monitoring or auditing to be conducted at a specific period rather indicated that records relating to monitoring should be made available for inspection to any relevant authority in respect of the power station development, condition 3.2.5.1 of the EA.

The regular and continual external audits for a project of enormous magnitude as Medupi are crucial in informing both the developer and the authorities on the compliance of the project against acquired permits and/or licenses. Therefore, the EA conditions should be specific to ensure this matter is well addressed by developers.

Incidents management: A number of incidents have been recorded such as the cement spills, hydraulic oil and diesel spills, killing and/ or dead animals and most of them attended to. However, the EA did not mention how to address the incidents. It has to be known that a project of enormous magnitude as Medupi cannot be expected to have no incidents. Therefore a specific condition on incidents management was necessary to be included in the EA.
Heritage resources: One grave was identified underneath the tree during initial stages of Medupi construction and it had to be relocated as it was where the main construction of the electricity units' plant should be located.

Improvements are required with specialists who conduct the heritage impact assessments to accurately advise the projects or developments on the actual impacts on heritage resources. This will ensure projects' timeous planning and budgeting for inclusion of possible relocation processes in the main project schedules. Contraventions for not acquiring required permits prior project execution could be avoided and the mindset change from perspective that environmental management issues delays development processes.

Biodiversity management: The Medupi development area is within a rich biodiversity area with more indigenous plant and animal species, more emphasize on biodiversity management was necessary by the authorities on the EA.

\section{Conclusions}

\section{The effectiveness of implementing and complying with the EA conditions}

Both projects generally showed effectiveness in implementation and compliance to the EA conditions as their compliance status never dropped below $90 \%$ compliance. However, the practicality of complying with certain conditions was noted to be a challenge. Kusile had noncompliance where a stream was diverted illegally; a Section $24 \mathrm{G}$ of NEMA was applied for and approved by DEA.

Kusile's non-compliance findings such as the excessive removal of vegetation, complains of more sediments at the downstream rivers, oil spills incidents; graves relocations were discussed and adequately addressed. The graves relocations followed proper process and acquired permit from SAHRA and oil spills were cleaned-up as well. However, no evidence on dealing with excessive removal of vegetation and complains of sediments in streams, were provided at the time of this research study.

Medupi did not have major non-compliance findings identified during this research study except for the incidents such as oil spills, killing of animals, poor storage of hazardous material and illegal dumping of hazardous substances. However, all the incidents were addressed. Medupi relocated one (1) grave and also like Kusile which relocated more graves about two hundred (200), it followed proper process of acquiring relocation permits.

Nevertheless compliance with most of the EA conditions were met by Kusile and Medupi, such as establishing the Environmental Monitoring Committee, installing an air quality ambient monitoring stations, compliance with the EMP, monitoring of the poultry farm at Kusile, conducting external audits and appointing Environmental Control Officers.

Therefore, it is concluded that the implementation and compliance to EA conditions for both the projects is effective.

\section{Sustainable development at the forefront of developments that obtained EA's and minimising environmental damage}

To answer the question of whether EA conditions ensure that sustainable development is at the forefront of developments that obtained EA's and minimises environmental damage is a very challenging question on its own. Legally, every development should adhere to a sustainable development project agenda and consider avoiding and/or minimising its environmental damage or footprint. 
Marshall et al., Arts et al. and Youthed [12,24,25] adequately explained the EIA follow-up, EIA has little value unless follow-up is carried out, because without it, the process remains incomplete and the consequences of EIA planning and decision-making will be unknown [24]. And Arts et al. [25] adding that there are questions about how do we know whether some additional action is needed to prevent unacceptable environmental impacts. And this calls for some follow-up to EIA to keep an eye on the real effects of project.

Youthed [12] also added that one of the advantages of follow-up is allowing learning from experiences to take place. This means that the EIA follow-up may assist in determining whether the EA conditions, as mostly drawn from the identified impacts of the EIA process, if implemented well could ensure sustainable development thereby minimising environment damage.

This study concluded that on the two case studies used, the EA conditions when well implemented and fully complied with will ensure that sustainable development is at the forefront of developments that obtained those EA's.

\section{Recommendations}

During the study it was discovered that Kusile unlike Medupi had many environmental issues that required careful detailed attention due to the environmental aspects of the surrounding area where the project development is located. These environmental issues needed to be dealt with adequately and timeously to avoid non-compliance. Unfortunately, the project ended up with a non-compliance which led it to apply for a Section 24G of NEMA, Act No. 107 [1] to rectify the illegal stream diversion activity.

To ensure that non-compliances do not occur, the whole project team (engineers, environmentalists, project managers, senior managers, ground workers, etc) should work together and be aware of the environmental aspects so that they can be able to identify red flags that could lead to non-compliances in advance and timeously.

The followings are recommended to ensure good implementation and full compliance of the EA conditions:

- The developers should conduct an environmental due diligence study prior to project construction in order to ensure that all environmental related permits and/or licenses were acquired and in place; identify the risks and potential non-compliances that could occur;

- Environmentalists should be involved in all processes of the development at initial stages in order to advise the project on environmental related issues;

- Educate the project team on the environmental issues and importance of compliance to environmental permits and/or licenses; and

- Furthermore, authorities issuing EAs should be encouraged to familiarise themselves with the environmental aspects of the project area of an activity and not use a blanket approach which results in some omission of crucial aspects to address when drawing conditions.

\section{Final Thoughts}

The importance of EIA follow-up has been shown by different authors as discussed in this study report. Generally, there is value in conducting an EIA follow-up in order to identify the reality of project implementation against expected impacts as was identified during the EIA process, from which the EA drawn its conditions from.

With this said, it can make a debatable discussions whether the EIA follow-up should be legislated and compulsory for listed activities as is with the BA or EIA processes. And if yes, how the lessons learnt for one development will be shared with another development and whether the development that used those lessons will be required to undergo its EIA follow-up as well.

The thoughts of the researcher based on outcomes of this study, is that EA compliance is achievable for willing developers who understand the need for environmental protection. The authorities also need to firm up their environmental protection role, identified environmental significant impacts of a project should be provided with stringent EA conditions aid the mitigation of such impacts.

EIA follow-up should be regulated as its outcomes play a crucial role in the EIA project circle. EIA process on its own is not a complete project circle for achieving sustainable development, if the actual impacts of such projects are not known and not adequately managed.

Additional to the authorities' inspections or audits for projects development, EIA follow-ups should be undertaken. Conducting EIA follow-up by authorities will eliminate biasness. Furthermore, environmental management is not about punishing developers but ensuring the sustainable development for environmental protection.

The researcher' opinion is that this study results can be applicable to other projects in a way that lessons can be learnt on the following:

- EAs should be adequately studied, well understood and all other related environmental permits or license should be acquired prior project execution;

- Relevant project stakeholders and management commitment is crucial throughout the project construction phase;

- EA and EMP trainings and awareness should be undertaken to all project implementers;

- Duty of care should be a common practice for environmental management with or without EAs; and

- Authorities should be engaged with throughout the project circle.

\section{Acknowledgements}

We would like to express our sincere gratitude to the leadership and several individuals within Eskom for their assistance, support and for granting us permission to undertake this study.

\section{References}

1. Government Gazette (1998) National Environmental Management Act. No.107. Cape Town: Government Printer, Republic of South Africa.

2. Christopher W (1995) Environmental impact assessment. A comparative review. Harlow, Longman.

3. Yako P (2006) Granting of conditional authorization for project reference 12/12/20/695. Construction of the proposed Eskom Holdings limited: Generation division $4800 \mathrm{MW}$ coal fired power station and associated infrastructure near Lephalale. Reference No. 12/12/20/695. Department of Environmental Affairs and Tourism, Pretoria, South Africa.

4. Eskom (2014) Kusile and Medupi Power Station

5. Ninham Shand Consulting Services (2007) Kusile Power Station Fina Environmental Impact Assessment Report. Eskom. Johannesburg, South Africa.

6. Senior Environmental Corporate Specialist (2014) Personal Communication Senior Environmental Corporate Specialist of Eskom Holdings SOC Ltd. 
Citation: Moja SJ, Molepo ME, Chadi GM (2016) A Review of the Environmental Authorization Followed During the Construction of Eskom's Kusile and Medupi Power Stations, South Africa. J Remote Sensing \& GIS 5: 176. doi: 10.4175/2469-4134.1000176

7. Government Gazette (1989) Environment Conservation Act No. 73: Environmental Impact Assessment Regulations 1182. Government Printer Pretoria, Republic of South Africa.

8. Bohlweki Environmental Consulting (2006) Medupi Power Station Final Environmental Impact Assessment Report. Eskom, Johannesburg, South Africa.

9. Senior Environmental Advisor (2015) Personal Communication. Senior Environmental Advisor of Eskom Medupi Power Station.

10. Morrison-Saunders A, Marshall R, Arts J (2007) EIA follow-up: international best practice principles. Special Publication Series No 6.

11. Creswell JW (2008) Research Designs: Qualitative, Quantitative and Mixed methods approaches. 3rd edn. Sage Publishers, Los Angeles, USA

12. Youthed JG (2009) Assessing and managing the potential for compliance default of applications submitted in terms of South Africa's environmental impact assessment regulations (Doctoral dissertation). UNISA, Pretoria, South Africa.

13. Jordaan I (2010) Environmental impact assessment follow-up in South Africa: critical analysis of predictions and compliance for the Mooi River Mall case study (Doctoral dissertation, North-West University).

14. Eskom (2015) Research, Testing and Development. Sustainability Division: Medupi Air Quality Monthly Report.

15. Welman JC, Kruger SJ (1999) Research Methodology for the Business and Administrative Sciences. Johannesburg: Thomson.

16. Van Schalkwyk M (2008) Record of decision for project reference 12/12/20/807:
Construction of the Eskom generation proposed 5400MW coal fired power station: Witbank. Reference No. 12/12/20/807. Department of Environmental Affairs and Tourism. Pretoria.

17. Government Gazette (2006) Environmental Impact Assessment Regulations. No. R385. Government Printer, Pretoria, Republic of South Africa.

18. Eskom (2012) Kusile Lessons Learnt Presentation.

19. Kusile Environmental Manager (2015) Personal Communication. Environmental Manager of Eskom Kusile Power Station.

20. Senior Environmental Corporate Specialist (2015) Personal Communication. Senior Environmental Corporate Specialist of Eskom Holdings SOC Ltd.

21. Government Gazette (1999) National Heritage Resources Act: Act No. 25 of 1999. Government Printer, Cape Town, Republic of South Africa.

22. Eskom (2014) South African commission for the promotion and protection of the rights of cultural, religious and linguistic communities: Feedback on Medup Heritage issues.

23. Medupi Environmental Manager (2015) Personal Communication Environmental Manager of Eskom Medupi Power Station.

24. Marshall R, Arts J, Morrison-Saunders A (2005) International principles for best practice EIA follow-up. Impact Assessment and Project Appraisal 23: 175-181.

25. Arts J, Caldwell P, Morrison-Saunders A (2001) Environmental impact assessment follow-up: good practice and future directions-findings from a workshop at the IAIA 2000 conference. Impact assessment and project appraisal 19: 175-185.

26. Google (2016) Earth Maps. 